\title{
Faktor-Faktor Kelewatan Tempoh Penyelesaian Kes Siasatan Cukai di Malaysia: Persepsi Ejen Cukai
}

\author{
(Factors Delaying the Settlement Period of Tax Investigation Cases in Malaysia: \\ Perception of Tax Agents)
}

\section{ROSIATI RAMLI, HELMY MOHD DAUD, ROMLAH JAFFAR \& MOHD MOHID RAHMAT}

\begin{abstract}
ABSTRAK
Penguatkuasaan siasatan cukai dilaksanakan bagi mengutip cukai yang sepatutnya dari aktiviti pelarian cukai melalui pembuktian dokumen dan penghadapan kes di mahkamah. Rangkakerja Siasatan Cukai menyarankan supaya sesuatu kes siasatan diselesaikan bagi tempoh 18 bulan jika menggunakan kaedah akaun ataupun 24 bulan jika menggunakan kaedah modal kerja. Namun, hasil kajian lepas menunjukkan berlakunya kelewatan dalam menyelesaikan kebanyakan kes siasatan cukai yang mengakibatkan kelewatan dalam kutipan cukai yang sepatutnya ini. Justeru kajian ini bertujuan untuk mendapatkan pandangan dari ejen-ejen cukai tentang faktor-faktor yang dianggap mempengaruhi tempoh penyelesaian kes siasatan cukai.Kajian ini telah memilih untuk menyoal selidik sebanyak 364 ejen cukai yang pernah terlibat dengan kes siasatan cukai. Kajian ini mendapati faktor strategi penguatkuasaan sebagai paling mempengaruhi, diikuti faktor kecekapan pegawai siasatan, teknik siasatan yang dgunakan, penalti cukai yang dikenakan, dan yang paling kurang mempengaruhi ialah pemahaman undang-undang cukai. Kajian ini merupakan yang pertama di Malaysia yang menggunakan ejen cukai sebagai responden. Hasil kajian ini dapat memberi input kepada pihak berkuasa cukai tentang strategi yang perlu digunakan bagi mengurangkan kelewatan tempoh penyelesaian kes siasatan cukai, dan seterusnya meningkatkan hasil kutipan cukai sebenar.
\end{abstract}

Kata Kunci: Siasatan cukai; tempoh penyelesaian; Lembaga Hasil Dalam Negeri Malaysia (LHDNM)

\section{ABSTRACT}

The enforcement of tax investigation is to collect the actual tax from tax evasion's activities through proof of documents and facing the case in court. Tax Investigation Framework recommends that a tax investigation case to be settled in 18 months if using the account method or 24 months if using the capital method. Nevertheless, previous studies showed that most tax investigation cases took longer than the suggested time to settle and caused delay in collecting the actual tax. Therefore, this study targeted to get perspective of the tax agents on factors which are considered as influencing the tax investigation's settlement period. This study chose to survey 364 tax agents who had experience in tax investigation. This study found that the enforcement strategy had been the most influential factor, followed by the competency of investigation officers, the investigation techniques being used, the tax penalties being charged, and the least influential had been the understanding of the tax laws. This study was the first in Malaysia that used the tax agents as respondent. Findings of this study could provide certain inputs to the tax authority on the recommended strategies to reduce the delay in the settlement period of tax investigation, and thus improve the actual tax collection.

Keywords: Tax investigation; settlement period; Inland Revenue Board of Malaysia (IRBM)

\section{PENGENALAN}

Masalah kelewatan tempoh penyelesaian kes siasatan cukai kian meruncing di Malaysia. Situasi ini tidak hanya menjejaskan keberkesanan penguatkuasaan siasatan cukai oleh Lembaga Hasil Dalam Negeri Malaysia (LHDNM), tetapi juga jumlah cukai sebenar yang sepatutnya dikutip. Mengapa situasi ini berlaku dan siapa yang perlu dipersoalkan menjadi bahan utama perbincangan kajian ini. Kajian berpandukan kepada Rangka Kerja Siasatan Cukai (RKSC) dan peraturan dalaman yang disediakan oleh LHDNM dalam melaksanakan aktiviti siasatan cukai. Ketetapan yang dibuat oleh LHDNM ialah sesuatu kes siasatan perlu diselesaikan tidak melebihi 18 bulan jika menggunakan kaedah akaun atau 24 bulan jika menggunakan kaedah penyata modal. 


\section{SOROTAN KAJIAN}

Penguatkuasaan siasatan cukai yang berkesan, khususnya secara siasatan jenayah, dapat mengurangkan jurang cukai dan meningkatkan sumber pendapatan negara (Dubin 2007). Berbeza dengan siasatan sivil dan audit, siasatan jenayah bertanggungjawab untuk mengheret ke mahkamah mana-mana pembayar cukai yang disyaki dan mempunyai bukti terlibat dengan pengelakan dan pelarian cukai. Penguatkuasaan siasatan cukai bagaimanapun kian hari menjadi semakin kompleks berikutan kelicikan pembayar cukai melakukan pengelakan dan pelarian cukai. Pengarah Jabatan Siasatan LHDNM membuat kenyataan bahawa antara cabaran utama yang dihadapi ialah penggunaan kaedah sofistikated oleh pembayar cukai untuk lari daripada membayar cukai, maka tindakan yang tegas dalam bentuk siasatan secara jenayah perlu diambil berbanding secara sivil (Sinar Harian 2014). Rasyidah (2017) melalui kajian ke atas individu yang mempunyai pendapatan tinggi mencadangkan supaya penguatkuasaan cukai dilaksanakan dengan lebih berkesan bagi mengenalpasti pelarian cukai serta membantu mencapai kadar pematuhan cukai yang tinggi. Kajian oleh Yee at al. (2017) ke atas 400 pembayar cukai di Malaysia menunjukkan kesedaran terhadap sistem dan undang-undang cukai di Malaysia dapat meningkatkan moral cukai di bawah sistem taksir sendiri.

Berbanding kebanyakan kajian lepas yang dilakukan ke atas penguatkuasaan audit cukai, kajian lepas berkaitan siasatan cukai di Malaysia adalah amat terhad atas sebab rahsia dan maklumat yang sukar didapati. Antara kajian yang dapat disorot ialah kajian oleh Helmy et al. (2018) yang telah menggunakan data dari pengkalan data di LHDNM untuk menerangkan tentang bentuk-bentuk pengelakan cukai yang kerap dilakukan oleh syarikat, ciri-ciri syarikat yang terlibat, dan juga purata bilangan kes siasatan cukai yang diselesaikan serta amaun penalti dan cukai tambahan yang dikenakan. Daripada sejumlah 838 syarikat yang dikaji, hasil kajian itu mendapati bentuk pengelakan cukai yang kerap dilakukan ialah pelarasan jualan melibatkan jualan kurang lapor, jualan dari aktiviti menyalahi undang-undang, dan jualan belum dilaporkan dari perniagaan perkongsian/pemilikan tunggal. Hasil kajian itu juga mendapati syarikat kecil dan sederhana yang mempunyai jualan di bawah RM500,000 setahun sebagai pelaku utama yang sering terlibat dengan kes siasatan cukai. Di samping itu, hasil kajian juga mendapati sektor yang paling kerap disiasat adalah perniagaan pemborong dan peruncit. Secara purata, kajian itu mendapati tempoh penyelesaian suatu kes siasatan adalah 22 bulan dengan kebanyakan kes melibatkan tempoh yang melebihi 18 bulan.

Kajian oleh Raig et al. (2015) pula menerangkan faktor-faktor yang mempengaruhi keberkesanan siasatan cukai melalui kajian temubual melibatkan pegawai siasatan di LHDNM. Terdapat empat faktor yang dikaji iaitu undang-undang cukai, kecekapan pegawai siasatan, penalti cukai, dan strategi penguatkuasaan. Hasil kajian itu mendapati faktor penalti cukai dan faktor strategi penguatkuasaan yang telah diambil oleh LHDNM adalah lebih mempengaruhi keberkesanan siasatan cukai berbanding faktor undang-undang dan kecekapan pegawai siasatan. Namun Swistak (2016) yang mengkaji peranan penalti cukai ke atas perniagaan kecil menunjukkan bahawa penalti cukai bukan merupakan faktor utama yang menyebabkan mereka memilih untuk tidak dikenakan siasatan cukai. Seterusnya kajian oleh Helmy et al. (2019) telah menambahbaik hasil kajian Raig et al. (2015) dengan melakukan kajian temubual ke atas pihak pengurusan atasan LHDNM untuk melihat semula pengaruh keempat-empat faktor berkenaan di samping menambah satu lagi faktor iaitu teknik siasatan. Teknik siasatan adalah tentang pemilihan samada menggunakan kaedah penyata modal atau kaedah akaun. Nawawi et al. (2018) mendapati kaedah penyata modal membantu siasatan cukai untuk mencegah pelarian cukai. Pihak pengurusan atasan LHDNM yang ditemubual itu adalah terdiri daripada empat orang pengarah bahagian yang kesemuanya terlibat secara langsung dalam penetapan strategi dan polisi bagi melaksanakan penguatkuasaan siasatan cukai di Malaysia. Hasil temubual kajian itu mendapati kesemua responden berpendapat bahawa hanya empat faktor, iaitu kecekapan pegawai siasatan, strategi penguatkuasaan, penalti cukai, dan teknik siasatan yang perlu dititikberatkan untuk memastikan tempoh penyelesaian sesuatu kes siasatan dapat dibuat mengikut tempoh yang disarankan oleh LHDNM. Selari dengan hasil kajian oleh Raig et al. (2015), faktor undang-undang dianggap tidak memberi kesan terhadap tempoh penyelesaian sesuatu kes siasatan cukai kerana responden berpendapat peraturan cukai telah termaktub dan sebarang pertikaian boleh dirujuk kepada Pesuruhjaya Khas Cukai.

\section{PENYATAAN MASALAH DAN PERSOALAN KAJIAN}

Di sebalik perlaksanaan siasatan cukai, aktiviti pengelakan dan pelarian cukai masih lagi berleluasa di Malaysia (Raig et al. 2015). Malah tiada bukti yang boleh menyatakan bahawa pengelakan cukai semakin berkurangan di Malaysia (Lai et al. 2013). Secara khusus, Laporan Tahunan LHDNM 2009 hingga 2013 menunjukkan trend pertumbuhan hasil kutipan cukai di Malaysia adalah semakin menguncup. LHDNM berjaya mencapai peratus lonjakan kutipan cukai yang tinggi pada tahun 2011 dengan 26.71 peratus berbanding pengurangan hasil kutipan cukai pada tahun 2010. Namun pada tahun 2012 dan 2013, walaupun hasil kutipan cukai meningkat tetapi peratus peningkatan kutipan cukai semakin mengecil dari 13.94 peratus kepada 3.24 peratus. Dalam keadaan di mana ekonomi dan permintaan dalaman negara yang terus berkembang, peratus kutipan cukai tidak sepatutnya menguncup melainkan berlakunya peningkatan dalam aktiviti pengelakan dan pelarian cukai.

Helmy et al. (2018) juga menunjukkan bahawa prestasi siasatan cukai di seluruh Malaysia adalah semakin merosot dengan bilangan kes siasatan mencatat pengurangan sebanyak 30 kes secara keseluruhan sejak tahun 2005 hingga 2014 
disebabkan masalah kelewatan tempoh penyelesaian sesuatu kes yang disiasat. Walaupun bilangannya kecil, implikasi penurunan bilangan kes siasatan cukai ini menyebabkan cukai kebelakangan yang dibangkitkan oleh siasatan cukai turut berkurangan sebanyak RM218.56 juta secara keseluruhan sejak dari tahun 2005 hingga 2014. Kajian oleh Helmy et al. (2018) juga mendapati kebanyakan kes yang disiasat telah melibatkan ejen cukai. Antara sebab utama mengapa pembayar cukai yang disiasat memilih menggunakan khidmat ejen cukai ialah kerana mereka kebanyakannya kurang berpengetahuan untuk terlibat sama dalam proses penyelesaian kes siasatan cukai. Helmy et al. (2019) seterusnya merungkai lima faktor yang menyumbang kepada masalah kelewatan tempoh penyelesaian ini dari perspektif pihak atasan LHDNM yang membuat polisi dan strategi ke atas penguatkuasaan siasatan cukai. Namun kajian itu tidak dibincangkan sama ada faktor-faktor berkenaan mempengaruhi tempoh penyelesaian kes siasatan cukai dari perspektif pihak pembayar cukai yang disiasat. Oleh kerana kebanyakan pembayar cukai yang disiasat menggunakan khidmat ejen cukai sebagai wakil mereka untuk berurusan dengan pegawai siasatan LHDNM, maka persoalan utama yang dibangkitkan oleh kajian ini ialah apakah persepsi ejen cukai tentang faktor-faktor yang dianggap mempengaruhi tempoh penyelesaian kes siasatan cukai? Faktor-faktor berkenaan ialah pemahaman undang-undang cukai, kecekapan pegawai siasatan, strategi penguatkuasaan, penalti cukai, dan teknik siasatan.

\section{METODOLOGI KAJIAN}

Ini adalah kajian empirikal melibatkan kaedah soal selidik ke atas ejen cukai yang dikenalpasti pernah terlibat kes siasatan cukai bagi tempoh 2012 hingga 2014. Senarai ejen-ejen cukai berkenaan diperolehi daripada laman sesawang LHDNM. Kajian mendapati bahawa sewaktu kajian ini dilakukan, populasi ejen cukai yang berdaftar di seluruh Malaysia adalah sebanyak 6,515. Berdasarkan Krejcie and Morgan (1970), saiz sampel yang sesuai bagi kajian ini adalah sebanyak 364. Atas kebenaran dari pihak LHDNM, kajian ini telah berjaya memilih secara khusus sejumlah 364 ejen cukai yang telah dikenalpasti terlibat dengan kes siasatan cukai. Namun pengedaran soal selidik yang dilakukan secara pos kepada mereka tidak dialamatkan kepada individu tertentu tetapi secara umum kepada pemilik atau pengarah syarikat ejen cukai yang dipilih.

Maklum balas terhadap penyataan dalam soal selidik kajian ini diukur menggunakan skala likert lima mata. Maklum balas sangat tidak setuju (STS) telah di nilai dengan skor 1, tidak setuju (TS) dengan skor 2, tidak pasti (TP) dengan skor 3, setuju (S) dengan skor 4, dan sangat setuju (SS) dengan skor 5. Sumber pembentukan item soal selidik di Jadual 1.

JADUAL 1. Sumber pembentukan soal selidik

\begin{tabular}{lcl}
\hline Faktor & Bil, item & Sumber Kajian Lepas \\
\hline Pemahaman undang-undang cukai & 9 & Long \& Swingen (1987), McKerchar (2005) dan \\
& 10 & Raig et al. (2015). \\
Kecekapan pegawai & 6 & Insch et al. (2008) dan Raig et al. (2015). \\
Strategi penguatkuasaan & 5 & Demrod \& Yitzhaki (1987) dan Raig et al. (2015). \\
Penalti cukai & 8 & RKSC (2009), Raig et al. (2015). \\
Teknik siasatan &
\end{tabular}

\section{ANALISIS DATA DAN PERBINCANGAN HASIL KAJIAN}

Kadar respon soal selidik kajian ini adalah sebanyak 31\%, di mana daripada 364 soal selidik yang diedarkan, 112 telah diterima dan sesuai serta lengkap untuk dianalisa. Ujian kenormalan berdasarkan nilai skor z menunjukkan bahawa data untuk kesemua faktor yang dikaji adalah bertaburan normal. Ujian kebolehpercayaan berdasarkan nilai Cronbach Alpha yang melebihi 0.7 pula menunjukkan bahawa setiap soalan yang mewakili faktor-faktor kajian boleh dipercayai serta dapat mengukur dengan tepat. Hasil kedua analisis ini ditunjukkan dalam Jadual 2 di bawah.

JADUAL 2. Nilai skor z dan nilai Cronbach Alpha

\begin{tabular}{lcccc}
\hline \multirow{2}{*}{ Pemboleh Ubah } & \multicolumn{2}{c}{ Ujian Kenormalan - Skor z } & \multicolumn{2}{c}{ Ujian Kebolehpercayaan } \\
\cline { 2 - 5 } & Skewness & Kurtosis & Bil. Item & Cronbach Alpha \\
\hline Pemahaman undang-undang cukai & -0.631 & -0.457 & 9 & 0.910 \\
Kecekapan pegawai & -0.260 & -0.132 & 10 & 0.885 \\
Strategi penguatkuasaan & -1.253 & 1.366 & 6 & 0.838 \\
Penalti cukai & -0.573 & 0.107 & 5 & 0.726 \\
Teknik siasatan & 1.016 & 1.647 & 8 & 0.826 \\
Jumlah & & & 38 & 0.785 \\
\hline
\end{tabular}

Kajian ini juga telah memeriksa data menggunakan analisis faktor dan berdasarkan Measures of Sampling Adequacy (MSA) dalam jadual anti-image correlation matrix melebihi nilai 0.5, Kaiser-Mayer-Olkin (KMO) melebihi 0.6, 
dan Bartlett's Test of Sphericity (BTS) signifikan pada $p<0.05$, dan mendapati kesemua 38 item soal selidik boleh diambilkira. Bagi menerangkan dapatan kajian, dua jenis analisis ke atas soal selidik telah dilakukan. Pertama adalah analisis mod atau kekerapan yang menerangkan latarbelakang responden kajian. Kedua adalah analisis purata untuk mengenalpasti faktor mana dari perspektif ejen cukai yang paling signifikan mempengaruhi tempoh penyelesaian kes siasatan cukai. Maklumat demografi responden ditunjukkan dalam Jadual 3 di bawah.

JADUAL 3. Maklumat demografi responden

\begin{tabular}{|c|c|c|c|}
\hline Ciri-ciri & & $\begin{array}{l}\text { Bilangan } \\
\text { (n) }\end{array}$ & $\begin{array}{c}\text { Peratusan } \\
(\%)\end{array}$ \\
\hline \multirow{2}{*}{ Jantina } & Lelaki & 79 & 70.54 \\
\hline & Perempuan & 33 & 29.46 \\
\hline \multirow[t]{4}{*}{ Umur } & $20-29$ tahun & 4 & 3.57 \\
\hline & $30-39$ tahun & 44 & 39.30 \\
\hline & $40-49$ tahun & 45 & 40.17 \\
\hline & 50 tahun ke atas & 19 & 16.96 \\
\hline \multirow{5}{*}{$\begin{array}{l}\text { Taraf pendidikan } \\
\text { tertinggi }\end{array}$} & Diploma & 2 & 1.79 \\
\hline & Ijazah & 85 & 75.89 \\
\hline & Ijazah Sarjana & 21 & 18.75 \\
\hline & $\mathrm{PhD}$ & 1 & 0.89 \\
\hline & Lain-lain & 3 & 2.68 \\
\hline \multirow{5}{*}{$\begin{array}{l}\text { Pengalaman bekerja } \\
\text { sebagai ejen cukai }\end{array}$} & Kurang daripada 5 tahun & 22 & 19.64 \\
\hline & 5 hingga 10 tahun & 28 & 25.00 \\
\hline & 11 hingga 15 tahun & 34 & 30.36 \\
\hline & 16 hingga 20 tahun & 15 & 13.39 \\
\hline & Melebihi 20 tahun & 13 & 11.61 \\
\hline \multirow{5}{*}{$\begin{array}{l}\text { Pengalaman } \\
\text { mengendalikan siasatan } \\
\text { cukai }\end{array}$} & Kurang daripada 5 tahun & 28 & 25.00 \\
\hline & 5 hingga 10 tahun & 45 & 40.18 \\
\hline & 11 hingga 15 tahun & & 23.21 \\
\hline & 16 hingga 20 tahun & 6 & 5.36 \\
\hline & Melebihi 20 tahun & 7 & 6.25 \\
\hline \multirow[t]{5}{*}{ Taraf jawatan } & Eksekutif Cukai Junior & 20 & 17.86 \\
\hline & Eksekutif Cukai Senior & 56 & 50.00 \\
\hline & Pengurus Cukai & 25 & 22.32 \\
\hline & Rakan Kongsi & 7 & 6.25 \\
\hline & Lain-lain & 4 & 3.57 \\
\hline \multirow[t]{2}{*}{ Pengkhususan } & Percukaian & 80 & 71.43 \\
\hline & Percukaian dan lain-lain khidmat akaun & 32 & 28.57 \\
\hline
\end{tabular}

Seperti yang ditunjukkan di Jadual 3, kajian mendapati majoriti ejen cukai yang terlibat dalam kajian ini adalah golongan lelaki, iaitu sebanyak 79 responden (70.54\%) berbanding ejen cukai perempuan sebanyak 33 responden (29.46\%). Kajian ini juga mendapati ejen cukai yang berumur lebih 40 tahun adalah lebih kerap terlibat dengan kes siasatan cukai iaitu merangkumi 64 responden $(57.00 \%$ ). Ejen cukai yang berumur 40 tahun ke atas biasanya lebih matang dan berkemahiran dalam mengendalikan kes siasatan dan ini mungkin menjadi faktor utama mengapa mereka lebih kerap terlibat. Hasil kajian ini seterusnya menunjukkan majoriti ejen cukai berpendidikan tinggi, iaitu ijazah dan ke atas merangkumi 110 responden. Ini bermakna kebanyakan ejen cukai yang terlibat dengan kes siasatan cukai adalah mereka yang mempunyai tahap pendidikan formal yang tinggi dianggap mampu memahami kaedah yang digunapakai oleh pihak LHDNM terutama di dalam perbincangan isu siasatan cukai.

Jadual 3 juga menunjukkan lebih daripada separuh responden memiliki pengalaman sebagai ejen cukai melebihi 10 tahun, iaitu merangkumi 62 responden (55.00\%). Ini menunjukkan bahawa ejen cukai yang dilantik menjadi wakil pembayar cukai untuk mengendalikan kes-kes siasatan kebanyakannya telah berkhidmat sebagai ejen cukai bagi tempoh melebihi 10 tahun. Faktor pengalaman sebagai ejen cukai ini diperlukan supaya kualiti kerja dan pengetahuan di dalam mengurus keskes siasatan cukai mereka berada pada tahap yang tinggi bagi memastikan pembayar cukai berpuas hati dengan hasil kerja mereka. Bagaimanapun, kajian mendapati ejen cukai yang memiliki pengalaman secara khusus mengendalikan kes siasatan bagi tempoh kurang dari 10 tahun adalah paling kerap terlibat di dalam kes siasatan cukai, iaitu sebanyak 73 responden $(65.00 \%)$. Berdasarkan tinjauan pengkaji, kebanyakan ejen cukai yang mempunyai pengalaman kurang dari 10 tahun di dalam mengendalikan kes siasatan cukai ini merupakan bekas pegawai yang pernah berkhidmat dengan LHDNM kerana bersara wajib. Jadi walaupun tidak begitu lama mengendalikan kes siasatan cukai sebagai ejen cukai, bagi pembayar cukai, perlantikan ejen cukai di kalangan pegawai LHDNM yang bersara lebih banyak membantu di dalam urusan dengan pegawai siasatan.

Jadual 3 seterusnya menunjukkan hampir kesemua ejen cukai yang mengendalikan kes siasatan cukai mempunyai jawatan berkaitan dengan cukai. Antara tugasan utama mengendalikan siasatan cukai adalah menterjemahkan akta, memahami garis panduan dan juga ketetapan cukai berkaitan dengan aktiviti siasatan cukai. Hanya mereka yang berjawatan berkaitan dengan cukai yang layak untuk melakukan tugasan berkenaan. Majoriti ejen cukai juga mempunyai pengkhususan 
di dalam percukaian sahaja iaitu sebanyak 80 responden $(71.43 \%)$ berbanding pengkhususan percukaian dan lain-lain iaitu sebanyak 32 responden (28.57\%). Pengkhususan ini penting bagi memastikan ejen cukai menumpukan sepenuhnya kepada kes-kes siasatan cukai yang dikendalikan tanpa melibatkan gangguan tugasan lain.

Seterusnya analisis kedua bagi menerangkan dapatan kajian ialah analisis purata yang dilakukan ke atas lima faktor berdasarkan bilangan kekerapan maklum balas. Secara keseluruhan, ianya ditunjukkan di Jadual 4 di bawah.

JADUAL 4. Analisis kekerapan dan purata faktor pemboleh ubah

\begin{tabular}{|c|c|c|c|c|c|c|c|}
\hline \multirow{2}{*}{ Faktor Pemboleh Ubah } & \multicolumn{5}{|c|}{ Kekerapan Maklum Balas } & \multirow{2}{*}{ Jumlah Skor } & \multirow{2}{*}{ Purata Skor } \\
\hline & STS & $\mathrm{TS}$ & $\mathrm{TP}$ & $\mathrm{S}$ & SS & & \\
\hline Pemahaman undang-undang cukai & 59 & 160 & 210 & 292 & 287 & 1,008 & 3.58 \\
\hline Kecekapan pegawai & 0 & 76 & 200 & 487 & 357 & 1.120 & 4.00 \\
\hline Strategi penguatkuasaan & 12 & 41 & 62 & 271 & 286 & 672 & 4.16 \\
\hline Penalti cukai & 32 & 81 & 83 & 195 & 169 & 560 & 3.70 \\
\hline Teknik siasatan & 27 & 66 & 149 & 285 & 369 & 896 & 4.00 \\
\hline Jumlah & 130 & 424 & 704 & 1,530 & 1,468 & 4,256 & \\
\hline
\end{tabular}

Jadual 4 menunjukkan bahawa secara keseluruhan responden bersetuju dengan kebanyakan persoalan yang dibangkitkan tentang kelima-lima faktor yang dianggap mempengaruhi tempoh penyelesaian kes siasatan cukai, iaitu sebanyak 1,530 maklum balas bersetuju dan 1,468 sangat bersetuju. Di segi peratusan, jumlah maklum balas bersetuju dan sangat bersetuju ini meliputi 70.44\% dari jumlah keseluruhan maklum balas. Secara khusus, jumlah maklum balas bersetuju dan sangat bersetuju bagi faktor pemahaman undang-undang cukai adalah masing-masing 292 dan 287, iaitu meliputi $57.44 \%$ dari jumlah maklum balas. Bagi faktor kecekapan pegawai, jumlah maklum balas bersetuju dan sangat bersetuju masing-masing 487 dan 357, iaitu meliputi 75.35\% dari jumlah maklum balas. Jumlah maklum balas bersetuju dan sangat bersetuju bagi faktor strategi penguatkuasaan pula adalah masing-masing 271 dan 286, iaitu meliputi 82.88\% dari jumlah maklum balas. Seterusnya bagi faktor penalti cukai, jumlah maklum balas bersetuju dan sangat bersetuju masing-masing 195 dan 169, iaitu meliputi 65\% dari jumlah maklum balas. Akhir sekali bagi faktor teknik siasatan jumlah maklum balas bersetuju dan sangat bersetuju masing-masing 285 dan 369, iaitu meliputi 72.99\% dari jumlah maklum balas. Berdasarkan jumlah maklum balas bersetuju dan sangat bersetuju ini, kajian membuktikan majoriti responden mempunyai persepsi bahawa kesemua lima faktor yang dikaji adalah dianggap mempengaruhi tempoh penyelesaian kes siasatan cukai.

Di segi faktor mana yang paling dianggap mempengaruhi, hasil analisis purata ini seterusnya menunjukkan bahawa faktor pemboleh ubah yang mempunyai skor purata yang paling tinggi mempengaruhi tempoh kes siasatan cukai adalah faktor strategi penguatkuasaan, iaitu sebanyak 4.16, diikuti oleh faktor kecekapan pegawai dan teknik siasatan dengan purata skor masing-masing sebanyak 4.00, faktor penalti cukai dengan purata skor 3.70, dan faktor pemahaman undang-undang cukai dengan purata skor 3.58. Ini bermakna daripada lima faktor yang dikaji, faktor strategi penguatkuasaan adalah dianggap paling mempengaruhi manakala faktor pemahaman undang-undang adalah paling kurang mempengaruhi.

Skor purata maklum balas ini juga diterangkan berdasarkan interpretasi seperti yang dicadangkan oleh Nunnally dan Bernstein (2006) seperti berikut.

\begin{tabular}{|cc}
\hline Interpretasi & Skor Purata \\
\hline Tinggi & $4.01-5.00$ \\
Sederhana Tinggi & $3.01-4.00$ \\
Sederhana & $2.01-3.00$ \\
Rendah & $1.01-2.00$ \\
\hline
\end{tabular}

Hasil analisis purata yang telah dijalankan ke atas lima faktor yang dikaji ditunjukkan di Jadual 5 hingga Jadual 9 di bawah.

JADUAL 5. Analisis purata faktor pemahaman undang-undang cukai

\begin{tabular}{llcc}
\hline \multicolumn{1}{c}{ Item } & Purata & Interpretasi \\
\hline 1. & $\begin{array}{l}\text { Saya perlu mengetahui terlalu banyak kadar cukai dan garis panduan penalti } \\
\text { cukai yang dikeluarkan oleh LHDNM di dalam kes penguatkuasaan cukai. } \\
\text { Saya perlu membaca dan memahami terlalu banyak peruntukan tambahan } \\
\text { (contoh: Ketetapan Umum dan Garis Panduan) dari pihak LHDNM untuk } \\
\text { menerangkan sesuatu perkara cukai. }\end{array}$ & 4.14 & Tinggi \\
3. $\begin{array}{l}\text { Saya perlu mengambil masa terlalu lama untuk memahami sesuatu seksyen yang } \\
\text { sukar di dalam undang-undang cukai. }\end{array}$ & 4.13 & Tinggi \\
4. $\quad \begin{array}{l}\text { Peraturan dan undang-undang dalaman LHDNM sukar difahami. } \\
\text { 5. } \begin{array}{l}\text { Kekerapan di dalam perubahan parameter cukai seperti kadar cukai dan penalti } \\
\text { menyebabkan undang-undang cukai lebih sukar difahami. }\end{array}\end{array}$ & 2.96 & Tinggi \\
6. $\begin{array}{l}\text { Saya perlu menghadapi sebarang perubahan peraturan LHDNM yang tidak } \\
\text { dijangka berhubung undang-undang cukai. }\end{array}$ & 4.15 & Sederhana Tinggi \\
\hline
\end{tabular}


7. Saya sentiasa merasa sukar dan menghadapi masalah untuk kemaskini semua perubahan yang relevan terhadap undang-undang cukai.

8. Kefahaman peruntukan tertentu undang-undang cukai terjejas oleh bahasa yang sukar difahami dan kabur.

9. Kesukaran memahami undang-undang cukai disebabkan interpretasi yang tidak konsisten.
3.10

2.99

3.57

3.58
Sederhana Tinggi

Sederhana

Sederhana Tinggi

Sederhana Tinggi

Jadual 5 menunjukkan skor purata bagi faktor pemahaman undang-undang cukai adalah sebanyak 3.58. Interpretasi bagi skor ini adalah pada tahap sederhana tinggi. Ini bermakna responden bersetuju dengan faktor yang dikaji pada tahap sederhana tinggi. Secara terperinci, terdapat empat item soal selidik tentang faktor ini yang mendapat skor purata pada tahap tinggi, iaitu item nombor 1, 2, 3, dan 6, masing-masing dengan purata skor sebanyak 4.14, 4.13, 4.14 dan 4.06. Item 1 adalah tentang keperluan mengetahui terlalu banyak kadar cukai dan garis panduan penalti cukai yang dikeluarkan oleh LHDNM, item 2 adalah keperluan untuk membaca dan memahami terlalu banyak peruntukan tambahan, item 3 adalah keperluan bagi mengambil masa terlalu lama untuk memahami sesuatu seksyen yang sukar di dalam undang-undang cukai, dan item 6 adalah keperluan bagi menghadapi sebarang perubahan peraturan LHDNM yang tidak dijangka berhubung undang-undang cukai.

Jadual 5 juga menunjukkan terdapat tiga item soal selidik tentang faktor pemahaman undang-undang cukai ini yang mendapat skor purata pada tahap sederhana tinggi, iaitu item nombor 5, 7 dan 9, masing-masing dengan purata skor sebanyak $3.15,3.10$, dan 3.57. Item 5 adalah tentang kekerapan di dalam perubahan parameter cukai seperti kadar cukai dan penalti menyebabkan undang-undang cukai lebih sukar difahami. Item 7 pula tentang sentiasa merasa sukar dan menghadapi masalah untuk kemaskini semua perubahan yang relevan terhadap undang-undang cukai. Item 9 adalah tentang kesukaran memahami undang-undang cukai disebabkan interpretasi yang tidak konsisten.

Seterusnya Jadual 6 menunjukkan terdapat dua item yang mendapat skor purata pada tahap sederhana, iaitu item 4 dan 8 , masing dengan purata skor sebanyak 2.96 dan 2.99. Item 4 adalah tentang peraturan dan undang-undang dalaman LHDNM sukar difahami, manakala item 8 adalah tentang kefahaman peruntukan tertentu undang-undang cukai terjejas oleh bahasa yang sukar difahami dan kabur.

JADUAl 6. Analisis purata faktor kecekapan pegawai

\begin{tabular}{|c|c|c|c|}
\hline & Item & Purata & Interpretasi \\
\hline 1. & $\begin{array}{l}\text { Saya percaya pegawai siasatan LHDNM memenuhi kelayakan akademik sebagai } \\
\text { pegawai siasatan ketika berurusan dengan pembayar cukai. }\end{array}$ & 4.17 & Tinggi \\
\hline 2. & $\begin{array}{l}\text { Saya melihat LHDNM perlu kerap melatih pegawai siasatan untuk } \\
\text { meningkatkan kemahiran penyiasatan. }\end{array}$ & 4.24 & Tinggi \\
\hline 3. & $\begin{array}{l}\text { Saya yakin berurusan dengan pegawai siasatan yang berpengalaman kerana telah } \\
\text { lama bekerja dan mempunyai lebih pengetahuan dan kemahiran di dalam } \\
\text { siasatan cukai. }\end{array}$ & 4.25 & Tinggi \\
\hline 4. & $\begin{array}{l}\text { Saya yakin berurusan dengan pegawai siasatan yang baru kerana telah diberi } \\
\text { tunjuk ajar dari pegawai berpengalaman ketika perbincangan penyelesaian kes. }\end{array}$ & 3.74 & Sederhana Tinggi \\
\hline & $\begin{array}{l}\text { Semasa berurusan, kelihatan pegawai siasatan telah diberi latihan perbelajaran di } \\
\text { dalam isu pengelakan cukai terkini. }\end{array}$ & 4.10 & Tinggi \\
\hline & $\begin{array}{l}\text { Saya melihat pegawai siasatan tidak membuat semakan secara terperinci kerana } \\
\text { tergesa-gesa menutup kes bagi tujuan mencapai sasaran prestasi. }\end{array}$ & 3.60 & Sederhana Tinggi \\
\hline & $\begin{array}{l}\text { Saya percaya pegawai siasatan yang bekerja secara berkumpulan lebih yakin dan } \\
\text { diterima pembayar cukai kerana keputusan penyelesaian adalah secara bersama. }\end{array}$ & 4.09 & Tinggi \\
\hline & $\begin{array}{l}\text { Saya percaya pegawai siasatan adalah berkemampuan dan bersiap sedia } \\
\text { menjalankan kerja siasatan secara individu. }\end{array}$ & 3.69 & Sederhana Tinggi \\
\hline & $\begin{array}{l}\text { Saya yakin pegawai siasatan cukai adalah berpengetahuan dan berkemahiran } \\
\text { selari dengan perkembangan isu semasa pengelakan cukai. }\end{array}$ & 4.07 & Tinggi \\
\hline & $\begin{array}{l}\text { Saya yakin berurusan dengan pegawai siasatan yang baru dengan dibimbing oleh } \\
\text { pegawai siasatan yang berpengalaman. }\end{array}$ & 4.10 & Tinggi \\
\hline & Jumlah & 4.00 & Sederhana Tinggi \\
\hline
\end{tabular}

Jadual 6 menunjukkan skor purata bagi faktor kecekapan pegawai adalah sebanyak 4.00. Interpretasi bagi skor ini adalah pada tahap sederhana tinggi. Ini bermakna responden bersetuju dengan faktor yang dikaji pada tahap sederhana tinggi. Secara terperinci, terdapat tujuh item soal selidik tentang faktor ini yang mendapat skor purata pada tahap tinggi, iaitu item nombor 1, 2, 3, 5, 7. 9 dan 10, masing-masing dengan purata skor sebanyak 4.17, 4.24, 4.25, 4.10, 4.09, 4.07 dan 4.10. Item 1 adalah tentang keyakinan berurusan dengan pegawai siasatan yang berpengalaman kerana telah lama berkerja dan mempunyai lebih pengetahuan dan kemahiran di dalam siasatan cukai, item 2 adalah keperluan LHDNM kerap melatih pegawai siasatan untuk meningkatkan kemahiran penyiasatan, item 3 adalah keyakinan berurusan dengan pegawai siasatan yang berpengalaman kerana telah lama bekerja dan mempunyai lebih pengetahuan dan kemahiran di dalam siasatan cukai, item 5 adalah kelihatan pegawai siasatan telah diberi latihan perbelajaran di dalam isu pengelakan cukai terkini, item 7 adalah percaya pegawai siasatan yang bekerja secara berkumpulan lebih yakin dan diterima pembayar cukai kerana 
keputusan penyelesaian adalah secara bersama, item 9 adalah keyakinan pegawai siasatan cukai adalah berpengetahuan dan berkemahiran selari dengan perkembangan isu semasa pengelakan cukai, dan item 10 adalah keyakinan yakin berurusan dengan pegawai siasatan yang baru dengan dibimbing oleh pegawai siasatan yang berpengalaman.

Jadual 6 juga menunjukkan terdapat tiga item soal selidik tentang faktor kecekapan pegawai ini yang mendapat skor purata pada tahap sederhana tinggi, iaitu item nombor 4, 6 dan 8, masing-masing dengan purata skor sebanyak 3.74, 3.60, dan 3.69. Item 4 adalah tentang keyakinan berurusan dengan pegawai siasatan yang baru kerana telah diberi tunjuk ajar dari pegawai berpengalaman ketika perbincangan penyelesaian kes. Item 6 pula tentang pegawai siasatan tidak membuat semakan secara terperinci kerana tergesa-gesa menutup kes bagi tujuan mencapai sasaran prestasi. Item 8 adalah tentang kepercayaan pegawai siasatan adalah berkemampuan dan bersiap sedia menjalankan kerja siasatan secara individu.

JADUAL 7. Analisis purata faktor strategi penguatkuasaan

\begin{tabular}{|c|c|c|c|}
\hline & Item & Purata & Interpretasi \\
\hline & $\begin{array}{l}\text { Saya fikir strategi penguatkuasaan LHDNM adalah mampan dan mempunyai } \\
\text { perbandingan yang baik dengan pentadbir cukai di rantau Asia Tenggara. }\end{array}$ & 4.24 & Tinggi \\
\hline 2. & $\begin{array}{l}\text { Saya percaya strategi semasa penguatkuasaan LHDNM boleh dikatakan } \\
\text { setanding dengan strategi penguatkuasaan pentadbir cukai yang lain. }\end{array}$ & 4.35 & Tinggi \\
\hline 3. & $\begin{array}{l}\text { Saya percaya strategi semasa penguatkuasaan LHDNM adalah konsisten dengan } \\
\text { objektif LHDNM untuk mengalakkan Pematuhan secara sukarela. }\end{array}$ & & Tinggi \\
\hline & $\begin{array}{l}\text { Saya percaya semua cawangan siasatan cukai di seluruh Malaysia adalah } \\
\text { konsisten di dalam pendekatan penguatkuasaan. }\end{array}$ & & Tinggi \\
\hline & $\begin{array}{l}\text { Kadang kala, saya ragu-ragu sama ada strategi semasa penguatkuasaan LHDNM } \\
\text { menyumbang kepada keberkesanan siasatan cukai di Malaysia. }\end{array}$ & & Tinggi \\
\hline & $\begin{array}{l}\text { Saya tidak ambil peduli strategi semasa penguatkuasaan LHDNM secara } \\
\text { keseluruhan. }\end{array}$ & & nggi \\
\hline & Jumlah & 4.16 & Tinggi \\
\hline
\end{tabular}

Jadual 7 menunjukkan skor purata bagi faktor strategi penguatkuasaan adalah sebanyak 4.16. Interpretasi bagi skor ini adalah pada tahap tinggi. Ini bermakna responden bersetuju dengan faktor yang dikaji pada tahap tinggi. Secara terperinci, terdapat empat item soal selidik tentang faktor ini yang mendapat skor purata pada tahap tinggi, iaitu item nombor 1, 2, 3, dan 4, masing-masing dengan purata skor sebanyak 4.24, 4.35, 4.23 dan 4.17. Item 1 adalah tentang tahap strategi penguatkuasaan LHDNM adalah mampan dan mempunyai perbandingan yang baik dengan pentadbir cukai di rantau Asia Tenggara, item 2 adalah kepercayaan strategi semasa penguatkuasaan LHDNM boleh dikatakan setanding dengan strategi penguatkuasaan pentadbir cukai yang lain, item 3 adalah kepercayaan strategi semasa penguatkuasaan LHDNM adalah konsisten dengan objektif LHDNM untuk mengalakkan Pematuhan secara sukarela, dan item 4 adalah kepercayaan bahawa semua cawangan siasatan cukai di seluruh Malaysia adalah konsisten di dalam pendekatan penguatkuasaan.

Jadual 7 juga menunjukkan terdapat dua item soal selidik tentang faktor strategi penguatkuasaan ini yang mendapat skor purata pada tahap sederhana tinggi, iaitu item nombor 5 dan 6, masing-masing dengan purata skor sebanyak 3.96, dan 3.98. Item 5 adalah tentang keraguan sama ada ada strategi semasa penguatkuasaan LHDNM menyumbang kepada keberkesanan siasatan cukai di Malaysia Item 6 pula tentang tidak mengambil peduli strategi semasa penguatkuasaan LHDNM secara keseluruhan.

JADUAL 8. Analisis purata faktor penalti cukai

\begin{tabular}{|c|c|c|c|}
\hline & Item & Purata & Interpretasi \\
\hline 1. & $\begin{array}{l}\text { Saya melihat rejim semasa penalti siasatan cukai yang dilaksanakan sekarang } \\
\text { berkesan untuk mempercepatkan tempoh penyelesaian kes siasatan cukai dan } \\
\text { pengelakan dan penipuan cukai oleh pembayar cukai. }\end{array}$ & 4.32 & Tinggi \\
\hline 2. & $\begin{array}{l}\text { Saya percaya bahawa penguatkuasaan siasatan cukai melalui peningkatan } \\
\text { penyelesaian bilangan kes disiasat setiap tahun akan meningkat pencegahan ke } \\
\text { atas pengelakan dan penipuan cukai di kalangan pembayar cukai. }\end{array}$ & 4.30 & Tinggi \\
\hline 3. & $\begin{array}{l}\text { Saya melihat penalti cukai tidak berkesan sebagai penghalang yang baik di } \\
\text { dalam mengekang kelewatan kes siasatan diselesaikan dan meningkatkan tahap } \\
\text { pencegahan terhadap pengelakan cukai. }\end{array}$ & 3.46 & Sederhana Tinggi \\
\hline 4. & $\begin{array}{l}\text { Berdasarkan pengalaman mengendalikan kes siasatan, kadar penalti cukai yang } \\
\text { tinggi tidak memberi berkesan kepada tempoh penyelesaian kes. }\end{array}$ & 3.06 & Sederhana Tinggi \\
\hline \multicolumn{2}{|r|}{$\begin{array}{l}\text { 5. Pengelak cukai harus didakwa sebagai melakukan kesalahan jenayah dan } \\
\text { dikenakan kesalahan yang berat seperti dipenjarakan untuk meningkatkan tahap } \\
\text { pencegahan. }\end{array}$} & 3.31 & Sederhana Tinggi \\
\hline & Jumlah & 3.70 & Sederhana Tinggi \\
\hline
\end{tabular}

Jadual 8 menunjukkan skor purata bagi faktor penalti cukai adalah sebanyak 3.70. Interpretasi bagi skor ini adalah pada tahap sederhana tinggi. Ini bermakna responden bersetuju dengan faktor yang dikaji pada tahap sederhana tinggi. Secara terperinci, terdapat dua item soal selidik tentang faktor ini yang mendapat skor purata pada tahap tinggi, iaitu item nombor 1 dan 2, masing-masing dengan purata skor sebanyak 4.32, dan 4.30. Item 1 adalah tentang rejim semasa penalti siasatan 
cukai yang dilaksanakan sekarang berkesan untuk mempercepatkan tempoh penyelesaian kes siasatan cukai dan pengelakan dan penipuan cukai oleh pembayar cukai, dan item 2 adalah kepercayaan bahawa penguatkuasaan siasatan cukai melalui peningkatan penyelesaian bilangan kes disiasat setiap tahun akan meningkatkan pencegahan ke atas pengelakan dan penipuan cukai di kalangan pembayar cukai.

Jadual 8 juga menunjukkan terdapat tiga item soal selidik tentang faktor penalti cukai ini yang mendapat skor purata pada tahap sederhana tinggi, iaitu item nombor 3, 4 dan 5, masing-masing dengan purata skor sebanyak 3.46, 3.06, dan 3.31. Item 3 adalah tentang penalti cukai tidak berkesan sebagai penghalang yang baik di dalam mengekang kelewatan kes siasatan diselesaikan dan meningkatkan tahap pencegahan terhadap pengelakan cukai. Item 4 pula tentang pengalaman mengendalikan kes siasatan terhadap kadar penalti cukai yang tinggi tidak memberi berkesan kepada tempoh penyelesaian kes. Item 5 adalah tentang pengelak cukai harus didakwa sebagai melakukan kesalahan jenayah dan dikenakan kesalahan yang berat seperti dipenjarakan untuk meningkatkan tahap pencegahan.

JADUAL 9. Analisis purata faktor teknik siasatan

\begin{tabular}{llcc}
\hline \multicolumn{1}{c}{ Item } & Purata & Interpretasi \\
\hline 1. & $\begin{array}{l}\text { Saya mudah memahami penemuan isu yang dibentangkan melalui kaedah } \\
\text { semakan akaun oleh LHDNM dalam mengenalpasti pengelakan cukai. }\end{array}$ & Tinggi \\
2. $\begin{array}{l}\text { Saya mudah memahami penemuan isu yang dibentangkan oleh LHDNM melalui } \\
\text { kaedah semakan penyata modal di dalam mengenalpasti pengelakan cukai. } \\
\text { Saya percaya kemahiran teknik siasatan dapat ditingkat melalui pengambilan } \\
\text { bukti dan maklumat pengelakan cukai dari sumber digital seperti komputer, } \\
\text { cakera keras dan lain-lain. }\end{array}$ & 3.33 & Sederhana Tinggi \\
4. $\begin{array}{l}\text { Berdasarkan pengalaman berurusan dengan cawangan siasatan, teknik siasatan } \\
\text { cukai sukar difahami menyebabkan kelewatan kes diselesaikan. }\end{array}$ & Tinggi \\
5. $\begin{array}{l}\text { Saya percaya kes siasatan lebih singkat diselesaikan apabila disemak secara } \\
\text { akaun oleh LHDNM. }\end{array}$ & Sederhana Tinggi \\
6. $\begin{array}{l}\text { Saya percaya kes siasatan lebih singkat diselesaikan apabila disemak secara } \\
\text { penyata modal oleh LHDNM. }\end{array}$ & 4.32 & Tinggi \\
7. $\begin{array}{l}\text { Saya percaya kes siasatan akan lebih singkat diselesaikan apabila pembuktian } \\
\text { penemuan isu siasatan menerusi pengambilan bukti secara digital oleh LHDNM. } \\
\text { Kaedah siasatan cukai akan menjadi yang paling efektif apabila bilangan } \\
\text { pegawai ditambah. }\end{array}$ & 3.32 & Sederhana Tinggi \\
\hline Jumlah & 4.19 & Sederhana Tinggi \\
\hline
\end{tabular}

Jadual 9 menunjukkan skor purata bagi faktor teknik siasatan adalah sebanyak 4.00. Interpretasi bagi skor ini adalah pada tahap sederhana tinggi. Ini bermakna responden bersetuju dengan faktor yang dikaji pada tahap sederhana tinggi. Secara terperinci, terdapat empat item soal selidik tentang faktor ini yang mendapat skor purata pada tahap tinggi, iaitu item nombor 1, 3, 5 dan 8, masing-masing dengan purata skor sebanyak 4.33, 4.37, 4.32 dan 4.19. Item 1 adalah tentang mudah memahami penemuan isu yang dibentangkan melalui kaedah semakan akaun oleh LHDNM dalam mengenalpasti pengelakan cukai, item 3 adalah kepercayaan kemahiran teknik siasatan dapat ditingkat melalui pengambilan bukti dan maklumat pengelakan cukai dari sumber digital seperti komputer, cakera keras dan lain-lain, item 5 tentang kepercayaan kes siasatan lebih singkat diselesaikan apabila disemak secara akaun oleh LHDNM, dan item 8 adalah kaedah siasatan cukai akan menjadi yang paling efektif apabila bilangan pegawai ditambah.

Jadual 9 juga menunjukkan terdapat empat item soal selidik tentang faktor teknik siasatan ini yang mendapat skor purata pada tahap sederhana tinggi, iaitu item nombor 2, 4, 6 dan 7, masing-masing dengan purata skor sebanyak 3.88, 3.88, 3.32, dan 3.77. Item 2 adalah tentang mudah memahami penemuan isu yang dibentangkan oleh LHDNM melalui kaedah semakan penyata modal di dalam mengenalpasti pengelakan cukai. Item 4 pula tentang pengalaman berurusan dengan cawangan siasatan, teknik siasatan cukai sukar difahami menyebabkan kelewatan kes diselesaikan. Item 6 adalah tentang kepercayaan kes siasatan lebih singkat diselesaikan apabila disemak secara penyata modal oleh LHDNM, dan item 7 adalah tentang kepercayaan kes siasatan akan lebih singkat diselesaikan apabila pembuktian penemuan isu siasatan menerusi pengambilan bukti secara digital oleh LHDNM.

Hasil analisis purata ke atas maklum balas soal selidik kajian ini mengesahkan bahawa kesemua faktor yang dikaji mempengaruhi tempoh penyelesaian kes siasatan cukai. Ini adalah berdasarkan purata skor yang diperolehi telah melebihi 3 dan berdasarkan interpretasi yang dicadangkan oleh Nunnally dan Bernstein (2006), purata skor yang melebihi 3 adalah pada tahap sederhana tinggi dan tinggi. Ini bermakna secara purata maklum balas yang diterima telah dipersetujui oleh responden sekurang-kurangnya pada tahap sederhana tinggi. Dapat disimpulkan di sini bahawa dapatan ini berjaya mencapai objektif kajian dalam mengkaji persepsi ejen cukai tentang faktor-faktor yang dianggap mempengaruhi tempoh penyelesaian kes siasatan cukai.

Secara khusus, hasil analisis purata ini juga telah membantu kajian untuk mengenalpasti faktor mana yang dianggap paling mempengaruhi tempoh penyelesaian kes siasatan cukai berdasarkan purata skor yang paling tinggi. Kajian mendapati bahawa faktor strategi penguatkuasaan mendapat purata skor yang paling tinggi, diikuti oleh faktor kecekapan pegawai, teknik siasatan cukai, penalti cukai, dan pemahaman undang-undang cukai. Ini bermakna dari perspektif ejen cukai, faktor utama yang menyebabkan berlakunya kelewatan tempoh penyelesaian kes siasatan cukai adalah disebabkan oleh 
penggunaan strategi penguatkuasaan oleh para pegawai siasatan LHDNM. Selain strategi penguatkuasaan, kecekapan pegawai siasatan, teknik siasatan yang digunakan, dan penalti cukai yang dikenakan juga merupakan faktor yang mempengaruhi tempoh penyelesaian kes siasatan cukai. Berdasarkan dapatan ini, jelas membuktikan bahawa tempoh penyelesaian kes siasatan lebih banyak dipengaruhi oleh institusi LHDNM itu sendiri, berbanding dari pihak ejen cukai.

Hasil kajian ini tentang keutamaan faktor strategi penguatkuasaan, kecekapan pegawai, dan penalti cukai berbanding faktor pemahaman undang undang cukai adalah selari dengan hasil kajian oleh Raig et al. (2015) dan Helmy et al. (2019). Dalam kajian ini, ejen cukai bersetuju bahawa strategi penguatkuasaan yang digunakan oleh pegawai siasatan perlu konsisten supaya kreadibiliti pegawai siasatan tidak dipertikaikan. Malah, bagi ejen cukai tindakan penguatkuasaan perlulah selari dengan objektif LHDNM iaitu meningkatkan pematuhan cukai secara sukarela. Di samping itu, tidak akan berlaku sebarang pertikaian ke atas tindakan yang dilakukan oleh LHDNM sekiranya siasatan cukai telah menunjukkan kejayaan di dalam memungut hasil cukai sebenar dengan mengurangkan aktiviti pengelakan cukai di seluruh negara. Strategi penguatkuasaan yang lemah akan menyebabkan pembayar cukai memilih untuk tidak patuh kepada perundangan cukai walaupun kebanyakan dari pembayar cukai sedar bahawa siasatan ke atas mereka akan dilakukan sekiranya cubaan mengelak cukai dapat dikesan oleh pihak LHDNM. Selain itu, strategi penguatkuasaan yang tidak telus dan lewat menyelesaikan kes yang disiasat turut menghakis keinginan pembayar cukai patuh. Perkara ini turut sama dibincangkan oleh kajian Sour (2001), Torgler (2003), dan Murphy (2004) bahawa tindakan penguatkuasaan cukai yang diambil amat mempengaruhi tahap pematuhan cukai. Terdahulu dari itu, kajian oleh Butler (1993) menyatakan bahawa tindakan penguatkuasaan yang berkesan khususnya melibatkan tempoh penyelesaian kes yang singkat boleh menukar sikap pembayar cukai dari negatif kepada positif. Berbanding kajian Raig et al. (2015) yang menyatakan siasatan jenayah diperlukan sebagai salah satu aktiviti utama penguatkuasaan, namun hasil kajian ini menyatakan sebaliknya, di mana menurut ejen cukai tindakan penguatkuasaan siasatan jenayah tidak perlu dijadikan sebagai aktiviti penguatkuasaan utama di dalam meningkatkan tahap pematuhan di negara ini. Tempoh penyelesaian yang lama dan juga bergantung kepada keputusan mahkamah akan menyebabkan urusan kes siasatan jenayah akan melangkau tempoh beberapa tahun untuk diselesaikan.

Selain penekanan kepada strategi penguatkuasaan, kecekapan pegawai siasatan juga perlu dititikberatkan bagi memastikan kes siasatan dapat diselesaikan dalam tempoh yang disarankan. Dalam kajian ini, ejen cukai menyatakan persetujuan bahawa pegawai siasatan perlu mempunyai kelayakan akademik supaya tidak berlaku kekeliruan dalam memperolehi isu pengelakan cukai yang dilakukan. Menurut mereka, pegawai siasatan perlu mengendalikan kes secara adil dan profesional serta menghadiri latihan supaya lebih cekap. Selain itu, mereka juga bersetuju bahawa pegawai yang lebih berpengalaman perlu membantu dan memberi tunjuk ajar kepada pegawai siasatan baru mengenai selok belok mengenalpasti pengelakan cukai supaya mereka mampu mengendalikan kes siasatan cukai dengan baik. Pegawai siasatan yang kurang pengalaman sepatutnya tidak dibiarkan bekerja secara bersendirian di dalam urusan kes yang diarah siasat. Malahan, ejen cukai bersetuju pegawai berpengalaman dan pegawai siasatan yang baru perlu diletakkan di dalam satu kumpulan yang sama bagi membolehkan pertukaran maklumat dapat dilakukan dan isu pengelakan cukai yang terkini dapat dikesan dengan mudah. Mereka juga bersetuju bahawa siasatan cukai tidak patut dilakukan secara individu bagi memastikan integriti pegawai siasatan tidak dipersoalkan. Kepentingan bekerja secara berkumpulan di dalam melaksanakan penguatkuasaan cukai ini turut sama dibincangkan oleh kajian Coburn (2006).

Hasil kajian ini mencadangkan supaya pegawai siasatan ditempatkan di satu bahagian atau cawangan untuk tempoh yang pendek dan sering ditukarkan ke bahagian lain supaya mereka dapat lebih didedahkan kepada persekitaran pengelakan cukai yang baru. Pegawai siasatan perlu diberi pendedahan kepada siasatan sektor industri yang melibatkan pengelakan cukai yang tinggi seperti di dalam kes kontraktor dan pemaju terutama yang terletak di Lembah Klang. Selain itu, dicadangkan juga supaya pegawai siasatan mengadakan perbincangan berterusan dengan jabatan-jabatan yang berkaitan seperi Jabatan Dasar Percukaian dan Jabatan Undang-undang LHDNM terutama di dalam isu-isu yang melibatkan penjelasan peruntukan undang-undang. Kecekapan pegawai siasatan mendapatkan penjelasan sesuatu isu undang-undang akan mengurangkan tempoh masa di dalam menyelesaikan kes siasatan cukai. Antara kes isu peruntukan undang-undang cukai yang memerlukan bantuan adalah pemakaian peruntukan di bawah seksyen 140 ACP 1967 yang memerlukan beberapa kriteria dipenuhi sebelum isu tersebut dibentangkan kepada pembayar cukai. Kegagalan pegawai siasatan mengenalpasti kriteria tersebut akan menyebabkan isu tersebut digugurkan sebagai isu pengelakan cukai.

Faktor ketiga yang didapati mempengaruhi tempoh penyelesaian kes siasatan cukai ialah teknik siasatan yang biasanya melibatkan pemilihan kaedah yang dibuat oleh pegawai siasatan, sama ada memilih kaedah akaun atau kaedah penyata modal. Kaedah akaun biasanya lebih sesuai digunakan dalam kes siasatan cukai syarikat, dan kaedah penyata modal pula lebih sesuai digunakan dalam kes siasatan cukai individu. Dalam kajian ini, ejen cukai bersetuju bahawa teknik siasatan yang digunakan adalah mudah difahami walaupun adakalanya terdapat kesukaran bagi memahami kaedah yang digunakan oleh pegawai siasatan. Namun, ini dapat diatasi setelah penjelasan yang terperinci dilakukan oleh pegawai siasatan cukai. Ejen cukai juga bersetuju bahawa pembentangan isu pengelakan cukai melalui kaedah akaun lebih mudah difahami berbanding pendekatan kaedah secara penyata modal. Antara sebab utama kaedah akaun lebih mudah diterima adalah kerana tempoh masa yang diambil oleh pegawai siasatan untuk menyediakan dokumen berkenaan isu pengelakan cukai adalah lebih pendek dan dapat mengurangkan tempoh masa pembayar cukai untuk menyediakan maklum balas. Sebaliknya, jika menggunakan kaedah penyata modal khususnya yang melibatkan pengarah syarikat dan para pemegang saham, tindakan menyediakan penyata modal yang lengkap memerlukan banyak dokumen individu yang perlu disiasat, dan sekiranya tiada dalam simpanan individu yang disiasat, maka dokumen perlu diperolehi daripada pihak ketiga. Akhirnya tempoh masa yang 
diambil bagi menyelesaikan penyata modal akan berpanjangan dan mengganggu pembayar cukai dari segi tumpuan masa di dalam penyediaan dokumen. Ejen cukai juga bersetuju bahawa pengambilan dokumen secara digital seperti di komputer syarikat dan cakera padat atau sebarang medium lain adalah sesuai bagi menyediakan bukti sama ada berlakunya isu pengelakan cukai atau tidak. Kajian oleh Chan et al. (2013) dan Drogalas et al. (2015) juga mencadangkan penggunaan dokumen secara digital adalah lebih memudahkan siasatan cukai. Selain itu, siasatan cukai perlu menambah bilangan pegawai siasatan supaya dokumen yang dirampas dapat disemak dan diperiksa secara keseluruhan dan tidak berpilih sahaja. Kajian oleh Khidzir dan Ahmed (2018) pula mendapati bahawa aspek yang paling utama di dalam forensik digital adalah untuk mengumpulkan bukti untuk digunakan di mahkamah bagi tujuan pendakwaan undang-undang. Makmal forensik digital pula perlu dikawal dengan kualiti dan kompetensi kerja-kerja forensik yang mendapat pengiktirafan antarabangsa (Guo \& Hou 2018). Seterusnya kajian oleh Alshebel (2020) juga menyatakan bukti digital perlu melalui pemeriksaan dan penganalisaan di makmal forensik digital dengan menggunakan perkakasan dan perisai komputer tertentu.

Perlu dinyatakan di sini bahawa kajian ini telah mengkaji secara berasingan di antara strategi penguatkuasaan dan teknik siasatan kerana strategi penguatkuasaan merupakan strategi secara umum yang merangka setiap langkah atau prosedur bagi mencapai indeks pencapaian prestasi secara keseluruhan siasatan cukai. Manakala, teknik siasatan pula merupakan kaedah atau alat secara spesifik yang membantu pegawai siasatan di dalam pencarian isu dan penemuan siasatan serta bukti kes siasatan cukai sama ada secara akaun mahupun secara penyata modal.

Hasil kajian ini seterusnya menunjukkan bahawa faktor penalti cukai mempunyai interpretasi purata skor pada tahap yang sederhana tinggi. Ini bermakna dari perspektif ejen cukai, faktor penalti adalah dianggap mempengaruhi tempoh penyelesaian kes siasatan namun tidak begitu tinggi berbanding faktor strategi penguatkuasaan, kecekapan pegawai, dan teknik siasatan. Dapatan ini adalah selari dengan beberapa kajian lepas seperti Kirchler (2007) yang menyatakan bahawa pelaksanaan penalti yang tidak berkesan boleh meningkatkan kadar pengelakan cukai. Ini khususnya berlaku sekiranya amaun penalti cukai yang dikenakan adalah lebih rendah berbanding manafaat yang diperolehi dari aktiviti pengelakan cukai. Dalam kajian ini, ejen cukai bersetuju bahawa penalti cukai masih diperlukan bagi mengurangkan tempoh penyelesaian siasatan cukai. Bermakna, lagi lama tempoh penyelesaian, lagi tinggi penalti yang dikenakan. Maka untuk kurangkan penalti, perlu kurangkan tempoh penyelesaian. Justeru, kajian ini mencadangkan supaya sebarang pengelakan cukai patut dikenakan tindakan yang tegas dengan kadar penalti yang dapat memberi kesan kepada tahap kesedaran pembayar cukai supaya tidak terlibat di dalam aktiviti pengelakan cukai. Penalti yang dikenakan sepatutnya memberi implikasi yang besar kepada aliran tunai kewangan syarikat serta individu itu sendiri yang mengakibatkan perbelanjaan seharian terpaksa dikurangkan. Kajian oleh Hor (2008) juga menyokong pelaksanaan penalti cukai dalam penguatkuasaan cukai khususnya bagi mengurangkan tempoh penyelesaian kes.

Oleh itu, kajian ini mencadangkan supaya pengenaan penalti dilaksanakan mengikut tahap proses siasatan dilaksanakan bagi mempercepatkan tempoh penyelesaian kes siasatan cukai. Bagi memastikan tempoh penyelesaian kes siasatan cukai dapat dikurangkan, tempoh masa semakan LHDNM dan maklum balas daripada pihak pembayar cukai perlu dihadkan. Malah, perlu dikenakan penalti sekiranya melebihi masa yang ditetapkan. Namun begitu, pihak LHDNM perlu memperkemaskan proses siasatan sedia ada terlebih dahulu supaya tidak wujud kekeliruan di kalangan pembayar cukai semasa dilaksanakan. Selain itu, ejen cukai menyatakan bahawa pegawai siasatan cukai perlu meningkatkan bilangan kes disiasat setiap tahun supaya dapat mengesan lebih ramai lagi pengelak cukai serta meningkatkan jumlah pungutan cukai. Sama seperti faktor penalti cukai, hasil kajian ini juga mendapati faktor pemahaman undang-undang cukai adalah mempengaruhi tempoh penyelesaian kes siasatan namun dianggap tidak tinggi berbanding faktor strategi penguatkuasaan, kecekapan pegawai, dan teknik siasatan. Dapatan menunjukkan ejen cukai memerlukan tempoh masa untuk memahami undang-undang cukai, terutama mengenai garis panduan dan ketetapan umum LHDNM. Sebarang perubahan peraturan oleh LHDNM menyebabkan ejen cukai kerap mengambil masa yang lama khususnya melibatkan garis panduan berkenaan pengenaan penalti cukai. Walaupun begitu, menurut ejen cukai sebarang peraturan dalaman LHDNM tidaklah terlalu sukar difahami kerana sentiasa diberi penjelasan lanjut oleh pihak LHDNM. Ejen cukai juga tidak menghadapi masalah dengan kekerapan berlakunya perubahan undang-undang cukai kerana bahasa dan interpretasi undang-undang cukai adalah konsisten serta sebarang kemaskini perubahan peruntukan akta boleh difahami dengan bantuan penjelasan oleh pegawai siasatan. Sekiranya masih berlaku kekeliruan berkenaan undang-undang cukai, ianya akan terus dirujuk kepada Pesuruhjaya Khas Cukai untuk diperjelaskan.

\section{KESIMPULAN}

Daripada hasil yang dibincangkan di atas, kajian membuat rumusan bahawa menurut persepsi ejen cukai, kesemua lima faktor yang dikaji didapati mempengaruhi tempoh penyelesaian kes siasatan. Bagaimanapun berdasarkan tahap pengaruh, kajian mendapati faktor strategi penguatkuasaan sebagai paling tinggi mempengaruhi, diikuti faktor kecekapan pegawai, teknik siasatan, penalti cukai, dan paling rendah mempengaruhi ialah faktor pemahaman undang-undang cukai. Berdasarkan dapatan ini, kajian telah membuat beberapa cadangan bagi membantu mengatasi masalah kelewatan tempoh penyelesaian kes siasatan cukai. 


\section{RUJUKAN}

Akta Cukai Pendapatan 1967(Act 53), Kuala Lumpur: International Law Book Services.

Allingham, M.G. \& Sandmo, A. 1972. Income tax evasion: A theoretical analysis. Journal of Public Economics 1(3-4): 323338.

Alshebel, A.K.S. 2020. Standardization Requirements for Digital Forensic Laboratories: A Document Analysis and Guideline. Doctoral dissertation, Auckland University of Technology.

Butler, C. 1993. Self assessment: The Way Forward. Tax Nasional, 2-3.

Chan, S., Chau, G. \& Leung, P. 2013. Tax audit and investigation in China and Hong Kong. International Tax Journal 39: $31-49$

Coburn, C.E. 2006. Framing the problem of reading instruction: Using frame analysis to uncover the microprocesses of policy implementation. American Educational Research Journal 43(3): 343-349.

Devos, K. 2009. An investigation into Australian personal 'tax evaders' - Their attitudes towards compliance and the penalties for non-compliance. Revenue Law Journal 19(1).

Drogalas, G. \& Karagiorgos, T. \& Arampatzis. K. 2015. Factors associated with internal audit effectiveness: Evidence from Greece. Journal of Accounting and Taxation 7(7): 114-122.

Dubin, J.A. 2007. Criminal investigation enforcement activities and taxpayer non-compliance. Public Finance Review 35(4): 500-529

Helmy, M.D, Ramli, R., Jaffar, R. \& Rahmat, M.M. 2018. Siasatan cukai di Malaysia: kajian penerokaan ke atas kes syarikat. Asian Journal of Accounting and Governance 10: 37-48.

Helmy, M.D., Ramli, R., Jaffar, R. \& Rahmat, M.M. 2019. Faktor-faktor mempengaruhi tempoh penyelesaian kes siasatan cukai di Malaysia: Perspektif pegawai pengurusan atasan LHDNM. Asian Journal of Accounting and Governance 11: 123-136.

Hor, Q.S. 2008. Taxmen at Your Doorstep: A Guide to Income Tax Enforcement. Pelanduk Publication.

Insch, G.S., McIntyre, N. \& Dawley, D. 2008. Tacit knowledge: A refinement and empirical test of the academic tacit knowledge scale. The Journal of Psychology 142(6): 561-580.

Guo, H. \& Hou, J. 2018. Review of the accreditation of digital forensics in China. Forensic Sciences Research 3(3): 194201.

Khidzir, N.Z. \& Ahmed, S.A.A.M. 2018. Towards fact-based digital forensic evidence collection methodology. Available at SSRN 3209396.

Kirchler, E. 2007. The Economic Psychology of Tax Behaviour. Cambridge University Press.

Krejcie, R.V. \& Morgan, D.W. 1970. Determining sample size for research activities. Educational and Psychological Measurement 30(3): 607-610.

Lai, M.L. \& Choong, K.F. 2008. Tax audit and tax evasion under the self assessment system: Survey evidence in Malaysia. Malaysian Law Journal, March-April.

Lai, M.L., Yaacob, Z., Omar, N., Aziz, N.A. \&Yap, B.W. 2013. Examining corporate tax evaders: evidence from the finalized audit cases. Proceedings of World Academy of Science, Engineering and Technology, 78-376. World Academy of Science, Engineering and Technology (WASET).

Laporan Tahunan 2009. Penerbit Lembaga Hasil Dalam Negeri.

Laporan Tahunan 2010. Penerbit Lembaga Hasil Dalam Negeri.

Laporan Tahunan 2011. Penerbit Lembaga Hasil Dalam Negeri.

Laporan Tahunan 2012. Penerbit Lembaga Hasil Dalam Negeri.

Laporan Tahunan 2013. Penerbit Lembaga Hasil Dalam Negeri.

Long, S.B. \& Judyth, A.S. 1987. An approach to the measurement of tax law complexity. Journal of the American Taxation Association 8(2): 22-36.

McKerchar, Margaret 2005. The impact of income tax complexity on practitioners in Australia. Australian Tax Forum 20(4): 529.

Murphy, K. 2004. The role of trust in nurturing compliance: A study of accused tax avoiders. Law and Human Behavior 28(2): 187-209.

Nawawi, A. \& Salin, A.S.A.P. 2018. Capital statement analysis as a tool to detect tax evasion. International Journal of Law and Management 60(5): 1097-1110.

Nunnally, J.C. \& Bernstein, I.H. 2006. Psychometric Theory.

Raig, J.T.P. 2015. Determinants of effective tax investigations in Malaysia from the tax authority's perspective. Unpublished PhD. Thesis, Curtin University, Australia.

Rangka Kerja Siasatan Cukai. 2007. Lembaga Hasil Dalam Negeri.

Rasyidah Che Rosli. 2017. Tax Malfeasance of high net-worth individuals in Malaysia: Archival Audited Data and Elite Interviews. Unpublished PhD. Thesis, UiTM.

Sinar Harian. 2014, 10 Julai. Giat Siasat Kesalahan Pelarian Cukai. Retrieved from http://www.sinarharian.com.my

Slemrod, J. \& Yitzhaki, S. 1987. The optimal size of tax collection agency. Scandinavian Journal of Economics 89: 183192. 
Sour, L. 2001. An economic model of tax compliance with individual morality and group conformity. Swistak, A. 2016. Tax penalties in SME tax compliance. Financial Theory and Practice 40(1): 129-147.

Torgler, B. 2003. Tax morale, rule-governed behaviour and trust. Constitutional Political Economy 14(2): 119-140.

Yee, C.P., Moorthy, K. \& Soon, W.C.K. 2017. Taxpayers' perceptions on tax evasion behaviour: An empirical study in Malaysia. International Journal of Law and Management 59(3): 413-429.

Helmy Mohd Daud

Fakulti Ekonomi dan Pengurusan

Universiti Kebangsaan Malaysia

43600 UKM Bangi, Selangor, MALAYSIA.

E-Mail: helmy@hasil.gov.my

Rosiati Ramli*

Fakulti Ekonomi dan Pengurusan

Universiti Kebangsaan Malaysia

43600 UKM Bangi, Selangor, MALAYSIA.

E-Mail: rosie@ukm.edu.my

Romlah Jaffar

Fakulti Ekonomi dan Pengurusan

Universiti Kebangsaan Malaysia

43600 UKM Bangi, Selangor, MALAYSIA.

E-Mail: romlah@ukm.edu.my

Mohd Mohid Rahmat

Fakulti Ekonomi dan Pengurusan

Universiti Kebangsaan Malaysia

43600 UKM Bangi, Selangor, MALAYSIA.

E-Mail:mohead@ukm.edu.my

${ }^{*}$ Corresponding author 